\title{
IDENTITY NEGOTIATION OF CHRISTIAN AND MUSLIM STUDENTS IN INTERACTION BETWEEN RELIGIONS IN LANGSA
}

\author{
Mawardi, Yusmami, Muhammad Suhaili Sufyan, Azwir \\ Institut Agama Islam Negeri Langsa \\ Jl. Meurandeh Langsa Lama, Kota Langsa, Aceh, 24354 \\ e-mail: mawardi.iainlangsa@ac.id,yusmami2ma@gmail.com, suhaily@iainlangsa.ac.id, \\ azwir@iainlangsa.ac.id
}

\begin{abstract}
This article describes how negotiation between the Christian and Muslim students in public place at Langsa. The objectives of the study are twofold, namely: the reason of Christian students deciding Langsa as the place of study despite different social condition from their own place and the pattern of negotiation conducted by the Christian students. Negotiation identity theory and national choice theory are used to know the reason of Christian students pointing Langsa as the place of study. using qualitative method with the phenomenal approach, it is found that the tolerance and harmony interaction between Christian and Muslims student in public place at Langsa. The pattern of negotiation used in public place at Langsa is: functional biculturalism that respect the different identity. this pattern is more effective to gain the culture shock and get the interaction easily the Christian and Muslim students in public place at Langsa.
\end{abstract}

\begin{abstract}
Abstrak: Negosiasi Identitas Mahasiswa Kristen dengan Muslim dalam Interaksi antar Agama di Kota Langsa. Tulisan ini menjelaskan pengalaman mahasiswa Kristiani bernegosiasi dengan mahasiswa Muslim dalam ruang publik di Langsa. Mendasarkan pada ruang sosial yang berbeda dengan kondisi mahasiswa Kristiani, pembahasan dimaksudkan untuk mengungkap alasan mahasiswa Kristiani memilih kuliah di Langsa yang berbeda kondisi sosial dengan daerah asalnya. Dengan menggunakan metode kualitatif dan pendekatan fenomenologis, didapatkan sebuah gambaran interaksi yang toleran antara mahasiswa Muslim dan Kristiani dalam ruang publik di Langsa. Adapun bentuk pola negosiasi yang dilakukan dalam ruang publik yaitu bikultarisme fungsional dengan menghargai identitas yang berbeda dengan aktor. Pola ini dianggap lebih efektif untuk menyelesaikan keterkejutan terhadap budaya baru dan memudahkan berinteraksi mahasiswa Kristiani dan Muslim dalam ruang publik di Langsa.
\end{abstract}

Keywords: negotiation, identity, interaction, Muslim, Christian, public place 


\section{Introduction}

Religion is a cultural system which is not only plays an integrative role and creates social harmony in society but it is also to break it down. ${ }^{1}$ It is a very careful statement describing the character of religious life. When religion is understood to be closed and radical it can cause collisions that continue to be conflict. Conversely, when the religion is understood opened and inclusive it will form a harmony. Between collision and harmony in religion come alternately in accordance with the negotiation that are built by different groups in dealing with other groups so that two influential attitudes are formed, namely; conflict and tolerance. This is a necessity, due to all religions are manifestations and forms of religion are from a single essence. ${ }^{2}$ To keep religious life away from conflict, tolerance becomes a collective awareness between religious people, both at the level of children and students. ${ }^{3}$

Regarding interreligious negotiations in Langsa, Ansor in his four studies described intolerant life in interreligious interactions. The study entitled 'Headscarves and Reproduction of Christian Women Identity in Aceh's Public School Space', Ansor examined how do Christian women life who have to wear headscarves as a form of negotiation in Muslim and Christian. ${ }^{4}$ Research entitled "Becoming like Other Religions: Hijab and Hybrid Identity Aceh Christian Students" also showed college public space to be a contestation area of unequal power between Muslim and Christian students in producing identity. The implementation of Islamic Shari'a as a formal law encourages the emergence of veiled Christian students. ${ }^{5}$

The study entitled Cross Behind the Headscarf; Negotiation of Veiled Christian Women Identity in Langsa, Ansor explained that the consequences of the Islamic law implementation have sparked the emergence of an identity for Christian women to wear headscarves, even though it is explicitly mentioned in the local regulation (Qanun), but at the social level it is a must for them to obey it. ${ }^{6}$ The research entitled 'We Are Different!' The Equality of

${ }^{1}$ Clifford Geertz, The Religion of Java (Chicago and London: The University of Chichago Press, 1960), p. 335.

${ }^{2}$ Manshuruddin, "Pola Kerukunan Antar Umat Beragama dalam Perspektir Forum Kerukunan Umat Beragama (FKUB) Sumatera Utara," in MIQOT: Jurnal Ilmu-ilmu Keislaman, Vol. 41 No. 2 2017, p. 447-495.

${ }^{3}$ Bahari, Toleransi Beragama Mahasiswa: Studi tentang Pengaruh Kepribadian, Keterlibatan Organisasi, Hasil Belajar Pendidikan Agama, dan Lingkungan Pendidikan terhadap Toleransi Mahasiswa Berbeda Agama pada 7 Perguruan Tinggi Umum Negeri (Jakarta: Badan Litbang dan Diklat Puslitbang Kehidupan Keagamaan, 2010), p. 2.

${ }^{4}$ Muhammad Ansor dan Cut Intan Meutia, "Jilbab dan Reproduksi Identitas Perempuan Kristen Ruang Publik Sekolah Aceh," in Kawistara, Vol. 6 No. 2 Agustus 2016, p. 157-174.

${ }^{5}$ Muhammad Ansor, "Menjadi Seperti Beragama Lain: Jilbab dan Identitas Hibrid Mahasiswa Kristen Aceh," in Penamas, Vol. 29, No. 1 April-Juni 2016, p. 11-30.

${ }^{6}$ Muhammad Ansor, "Salib Dibalik Jilbab: Negosiasi Identitas Perempuan Kristen Berjilbab di Langsa Aceh," in Proceeding ACIS XIV, 2014, p. 274-290. 
Young Muslim women and young Christian Women in Langsa, Aceh. In this case, Ansor stated that women had difficulty doing various professions if they were dressed differently. The public would prejudice against those who were not veiled. ${ }^{7}$ Ansor's data shown that the lived of Christian women in Langsa were in complicated negotiations. Socially they are required to be part of another social system with different identity as a form of negotiation and tolerance.

It can be seen different phenomena at the current time. Even different from Miswari's research on the phenomenon of Christian minorities in Aceh Tamiang won the sympathy of the majority to be recognized identity. ${ }^{8}$ Student of different religions negotiate their identities. They look joking together despite different identities so that they show a harmonious life. Even though non-Muslim students are a minority, there is no discrimination in association. They were free to present their identities in the public sphere, especially in terms of dress, it is no longer veiled Christian students.

The social shift displayed by Muslim and non-Muslim students in Langsa public were not unprocessed. There were negotiations built by both of them to create a tolerant life. The problem is how did they do it? This is where the significance which must be answered in this article. So this paper becomes interesting when the process of identity negotiation between Muslim and non-Muslim students becomes the main focus of the research.

Several studies related to the issue have been carried out, including; Research conducted by Sekar Ayu Aryani about Orientation, Attitude and Religious Behavior; Case Study of Students from One of the State Universities in DIY) ${ }^{9}$, Research by Ignasius Resky Alsuka Randa who examined the Attitude of Student Tolerance across Ethnics and Religion in Bujang Malaka Dormitory, Kubu Raya Regency. ${ }^{10}$ These studies have not touched on the realm of what it is carried out by this research, both in terms of objects and location. Researches which have similar location were conducted by Ansor in his four studies, entitled: Headscarves and Reproduction of Christian Women's Identity in Aceh School Public Spaces ${ }^{11}$, Becoming like Other Religion: Hijab and Hybrid Identity of Christian Acehnese Students, ${ }^{12}$ Cross behind the Hijab; Identity Negotiations of Veiled Christian Women in Langsa ${ }^{13}$, We Are Different!

${ }^{7}$ Muhammad Ansor, "Kan Kan Berbeda!: Persamaan Remaja Perempuan Muslim dan Kristen di Langsa Aceh," in Harmoni, Vol. 13 No. 2, 2014, p. 37-50.

${ }^{8}$ Miswari, "Mu'dilat al-Aqlyah al-Masâhîyah fî Hudûd Balad al-Shar'ah al-Islâmyah", in Studia Islamika, Vol. 25, No. 2, 2018, p. 351-402.

${ }^{9}$ Sekar Ayu Aryani, "Orientasi Sikap dan Perilaku Keagamaan: Studi Kasus Mahasiswa Salah Satu Perguruan Tinggi Negeri di DIY," in Religi: Jurnal Studi-Studi Agama, Vol. XI, No. 1, Januari Tahun 2015, p. 59-79.

${ }^{10}$ Ignasius Resky Alsuka Randa, "Sikap Toleransi Mahasiswa Lintas Etnis dan Agama di Asrama Bujang Malaka Kabupaten Kubu Raya," in Journal Pendidikan dan Pembelajaran, Vol. 6, No. 32017.

${ }^{11}$ Ansor dan Meutia, "Jilbab dan Reproduksi Identitas", p. 157-174.

${ }^{12}$ Ansor, "Menjadi Seperti Beragama Lain", p. 11-30.

${ }^{13}$ Ansor, "Salib Dibalik Jilbab," p. 274-290. 
Similarities between Muslim and Christian Women in Langsa, Aceh. ${ }^{14}$ Even though the location of the study was the same but the research period and the object of research are different.

The study applies the Identity Negotiation Theory by Stella Ting-Toomey. Toomey defines the Identity Negotiation Theory is the theory concern about negotiating two different identities. ${ }^{15}$ In addition, to support the theory and to get the reasons for choosing an area with a different identity, it is used James S. Coleman's rational choice theory. Rational Choice Theory is a theory that focuses an attention on actors who are seen as human who have purposes or aims. ${ }^{16}$ Choosing these two theories based on the classification of the problems studied in this research: the stages of reasoning to be in different cultures will be examined by rational choice theory. After being in a different environment, the actor will negotiate his identity, will it be accepted? It will be analyzed by using the identity negotiation theory.

\section{Research Method}

The study is an exploratory qualitative which aims at exploring Muslim and nonMuslim students negotiation in Langsa. To get complete and accurate data, researcher applied phenomenology approach. ${ }^{17}$ Data were collected through documentation, in-depth interview and unstructured interviews, Focus Group Discussion (FGD) with various communities. And participatory observation is performed according to the topics based on the guideline. Interviews were conducted to Christian and Muslim students. The selection of informants is conductive purposively. During data collection, the researchers sporadically met both parties. At least 10 meetings held to conduct interview. Documentation study is carried out to obtain information about the view and religious behavior of the subjects. This data analyzed along with data obtained through interviews from informants. Observations were conducted to obtain information about their social behavior, it was carried out to observe their daily life in socializing, both when with Muslim students or their fellow.

The Data will be analyzed through some steps, they are; data reduction, data display and conclusion drawing or verification ${ }^{18}$ First, taking note about all findings of phenomena in the field through observation, in-depth interviews, and documentation studies in the form of daily field notes. Second, reviewing the results of observations, interviews and documentations,

\footnotetext{
${ }^{14}$ Ansor, "Kan Kan Berbeda," p. 37-50.

${ }^{15}$ Stella Ting-Toomey, Communication Across Cultures (London: The Guldford Press, 1999), p. 29.

${ }^{16}$ Daniel Kahneman and Amos Tversky, "Choices, Values, and Frames," in American Psychologist Association (APA): University of British Colimbia, April 1984, p. 341-350.

${ }^{17}$ John W Creswell, Research Design: Qualitative, Quantitative and Mixed Methods Approaches Second Edition (California: Sage Publication, Inc, 2003), p. 15.

${ }^{18}$ A. Michael Huberman and B. Milles Mattew, "Manajememen Data dan Metode Analisis," in Norman K . Denzim dan Yvonna S. Lincoln, Handbook of Qualitative Research, terj. Dariyanto et al. (Yogyakarta: Pustaka Pelajar, 2009), p. 592.
} 
and separating the due to important and not important data. This activity is repeated to check for possible classification errors. Third, describing the data that has been clarified for further study by paying attention to the focus and purpose of the study. Fourth, final analysis for report writing. In this series, the data analysis process is carried out.

\section{Result and Discussion}

\section{Life Objective Condition of Muslim dan Non-Muslim Students}

The results from several studies had been carried out shows that the conditions of students in Langsa still display cultural uniformity. The implementation of Islamic Shari'a in daily interaction was very visible from the way they dress, so that the visualization of public spaces did not seem to have different religions. It does not mean that there were no non-Muslim students, a strong cultural context with the spirit of Islamic Shari'a required them to interpret religious symbolic identity in different cultures. The surrounding social culture required them to wear headscarves in public spaces, including when they were in college. ${ }^{19}$ So that cultural practices were displayed more uniformly, even though it is through diverse identities.

It is different from the current phenomena, the social interaction displays by students shows the diversity. In everyday life students do not only display ethnic differences (Javanese, Acehnese, Bataknese, etc.), but it is easier to find students of different ideologies and beliefs as well. Many non-Muslim students (Cristian) interact and negotiate and they are able to visualize their identities in the social space of Muslim communities. They are looked free in identifying themselves when they are in the community or in the world of education. The condition is increasingly apparent due to the increasing number of non-Muslim students.

Thus, the social reality of students in Langsa is seen by two groups of students interacting and negotiating, namely Muslim students and non-Muslim (Christian) students. Muslim students are the majority students in Langsa. They are spread in all the colleges in Langsa, both state universities such as State University of Samudra (Unsam), and the State Institute for Islamic Studies (IAIN), and private universities as well as, such as STIKES, STAI-IT, STIES, and so on. Initially, the presence of Muslim students in Langsa was limited to local students and they are form districts around Langsa (East Aceh and Tamiang). Along with the rapid development of universities and the realization of two main universities in Langsa from private to state universities, students who come to continue to study to Langsa come from various districts of Aceh, even from other provinces throughout Indonesia.

Non-Muslim students are minorities; generally they come from outside of Aceh. Information presented by Iyut that the number of non-Muslim students in Langsa reached

\footnotetext{
${ }^{19}$ Ansor, "Menjadi Seperti Beragama Lain," p. 11-30.
} 
130 students from various tribes and regions of Sumatra. There are some students from South Sumatra, but from those students are dominated by students from North Sumatra. ${ }^{20}$ Although there are differences in origin and ethnicity, all Christian students in Langsa take shelter under the Permanas organization (Christian Student Association). This organization is instead of a meeting place for all Christian students in Langsa, and it is also as a facilitator and mediator for new students. For example, Permanas helps students to find homes or shop-houses (ruko) to become residence. It also facilitates students in various matters in college.

Regarding the choice of residence, some non-Muslim students are grouped and lived with other Christian students. But there are also some others non-Muslim students who spread and lived with Muslim students. Students who are grouped, and live with other Christian students choose to rent a house or shop, usually they were facilitated by the Permanas organization. There are several locations to be their living places, such as; Sinar Mata's house located in Kampung Sidorejo, Pak Simbolon's house located in Sidodadi, Meurandeh's new street shop, Pak Joko's house, and boarding house street Kampong Teungoh. For Christian students who choose to live with Muslim students, they spread in several boarding houses around college. Generally, they prefer to live in the areas that are close to college such as boarding houses around Elementary School (SD) in Meurandeh, boarding houses close to IAIN Langsa, and some other boarding houses that are considered strategic and easy to reach to the college.

It is no different from Christian students, some Muslim students choose to lived among Muslims students and others lived with non-Muslim students in different social spaces. For Muslim students choosing to lived together or lived in conditions of different social spaces is not a problem because Langsa is a representation of their identity. Unlike non-Muslims, they have to interact and negotiate due to the identity of the Langsa community is different from what they present.

The most basic differences between Muslim from non-Muslim students are religious belief which includes prominent beliefs and ritual activities (ceremonies, ordinances, prohibitions). The differences in belief system have implications on the actions and behavior of each student. Then there will be certain aspects that are prohibited by Muslim students, but they are allowed by Christian students, one of the examples is dressing. Muslim students have their own style and dress pattern that is in accordance with the provisions of their religion. For Muslim students, dressing is not just a style, but there is an order of the Shari'a to cover aurat. Therefore, in everyday life Muslim students are seen wearing clothes based on the regulations of Shari'a through long pattern and wearing headscarves.

Contrasting to Muslim students, their dress patterns have no religious provisions, it is only neat, polite and clean demands. As Eka informed that she was never recommended

${ }^{20}$ Interview with Iyut Chair Permanas (Persatuan Mahasiswa Nasrani) in Langsa, date 29 August 2018. 
by Pastor to wear certain clothing patterns. The suggestions is only to dress modestly, neatly, and cleanly. So, we just adjust it as the Pastor's direction. ${ }^{21}$ Because there are no demands to dress in a certain way, the clothes worn by non-Muslim students accordingly, but it is still adapted to the conditions, including respecting the provisions of dressing in Langsa by dressing loosely and not too short.

Different phenomena in dressing between Muslim and non-Muslim students in Langsa show a variety of life in Langsa. Muslim students can visualize their identity in social spaces, and non-Muslim students also can easily to do it. So that, there is no domination and discrimination against minority

\section{Rational Thinking for Choosing to be a Part of the Different}

The description above shows a significant difference between Muslim and nonMuslims students. The difference that is felt is the system of each religious belief. The implication is that there are two different identities in one social space. If you look at the socio-religious conditions in Langsa it is actually an obstacle for non-Muslims. Moreover the application of Islamic law is as a regional rule, it is further adding to the alienation of non-Muslim in the social space. Even though those rules were not applied to them, but the impact of social-religious practices carried out daily by community in Langsa would create them feel as foreigners. It is different from North Sumatra, it tends to be pluralist, ${ }^{22}$ the interaction intensity between religions is very high, it makes them easier to negotiate. For example, the story of Uus that she had to fast in Ramadan because she forgot to prepare a meal at night. In the same month, Sinar also felt the condition where she had to hold thirst because the water in the dispenser was run out. Likewise, Marcus's story had to be embarrassed when he went out from living place at 12 on Friday, and many other stories were experienced at the beginning of their existence in Langsa. Those conditions require them to be able to adjust themselves as much as possible with the religious social space in Langsa.

It is viewed from the point of James S. Coleman's rational choice theory, the choice of the location of educational institutions and boarding houses for Muslim and non-Muslim students in Langsa are certainly based on a rational choice, and the rationality is determined by the purpose. The clearer the determined goals will be more rational in determining an action. Thus, to see the level of rationality must be measured as objectively as possible through the individual concerned it is not with other individuals, because rational for one individual is not necessarily for another individual. ${ }^{23}$ As it is also related to the condition of students

${ }^{21}$ Interview with Eka, Student at Samudra Langsa University in Langsa, date 09 September 2018.

${ }^{22}$ Irwansyah, "Interaksi Muslim dan Kristiani dalam Ikatan Kekerabatan di Sumatera Utara," in MIQOT: Jurnal Ilmu-ilmu Keislaman, Vol. 41 No. 1, Januari-Juni 2017, p. 209-229.

${ }^{23}$ James Coleman, Dasar-Dasar Teori Sosial (Bandung: Nusa Media, 2011), p. 17-18. 
in Langsa, it is for sure they have rational reasons to study in Langsa, even though they have to be in different social conditions.

If it is analyzed the selection of studying in Langsa and choosing boarding houses for Muslim and non-Muslim students is largely determined by values and preferences. Actually when students choose a college or boarding house they faced various preferences, but they remain in the choices that are being undertaken. Making choice is not formed by itself, but through a long process of thought. James S. Coleman mentions in rational choice theory as something purposive. Where the actors create certain rational reasons for doing action. ${ }^{24}$ The reasons chosen are closely related to the benefits achieved. So, rational in this context is the actor's advantage in making choices. At least there are two advantages that students get for choosing a college and boarding houses in Langsa, namely: economic and social.

Economically, living cost in Langsa is also cheaper than the living cost from the area where students coming from. From the information conveyed, some students acknowledged the low of living cost in Langsa. Retno admitted that living in Langsa did not need to spend a lot of money. We can eat by having only Rp. 4000, we can buy mixed ice by Rp. 3000 and there are still many other things that can be bought by students. Likewise Santi acknowledges that shopping in Langsa is happy due to many items are cheaper, especially for food sold in stalls. This phenomenon not only benefits students but their parents as well. Socially, the community life of Langsa is better than others and it becomes an advantage factor for students who are choosing it as a rational choice. Mark's assumption who encourage his son to study in Langsa despite different identities. For Mark, the implementation of Islamic law able to create a conducive culture. Socio-religious difference in Langsa were instead used as an advantage by Mark's family when they are determining to direct Markus to study to Langsa. It shows that the actor has actually minimized the risk to achieve maximum profit. ${ }^{25}$ Related to the issue of risk and profit, Kahneman and Tversky said that the risk of choosing to take an action can not affect the actor when it is resulting greater profit. ${ }^{26}$ The problem is on how to determine the benefits for the actor, in this case Mark as an actor can compare the other preferences as alternatives, even if the profit is an economic achievement.

From the description above shown that how Muslim and non-Muslim students have rational reasons for choosing to study to Langsa, especially, there are other factors that support agent choice, that is campus socialization. Coleman said corporate actor. Coleman defined that corporate actor is as complementary actor with natural personality. ${ }^{27}$ The

${ }^{24}$ Ibid, p. 23.

${ }^{25}$ Meita Arsita, et al, "Rasionalitas Pilihan Orang Tua Terhadap Pesantren sebagai Lembaga Pendidikan Remaja Awal, Sosialitas," in Journal Ilmiah Pendidikan Sosiologi-Antropologi, Vol. 5 No. 2, 2015.

${ }^{26}$ Kahneman and Tversky, "Choices, Values, and Frames," p. 341.

${ }^{27}$ Coleman, Dasar-Dasar Teori, p. 524. 
position of corporate actor and the actors are "the controller of resources and events, interests toward resources and events, and they have the ability to take actions to achieve their interests through controlling." ${ }^{28}$ Here, state university of Samudra which is considered as corporate actor also carried out various adaptations on community culture, the adaptation was conducted through disseminating information about the acceptance of new students at State University of Samudra Langsa. The effort was made to meet the needs of human resources, as well as to get benefit from many students who were interested in studying at Samudra Langsa.

From various reasons and motives behind the choosing universities in Langsa, it can be concluded that the students' rational choice studying in Langsa is based on two main factors, they are: experience value and decision value. Experience value in relation to "college choosing" is on the consideration of benefit and loss aspects. Actors who choose college in Langsa will be very sure on their choice due to the benefits given are greater than other alternatives. For them, the adequacy of needs is happiness, and the adequacy is impossible to get from minimum income. Choosing to study in Langsa will provide them more benefits even though it has only been at a minimum level, with income being slightly higher than the previous profession. Decision value in relation to "choosing a college in Langsa", it is for sure that the actors will choose an institution by comparing it to the previous institution.

Here is a supposition was built by Kahneman and Tverky on the issue of choosing something, comparing previous experiences to the experience of drinking a cup of coffee in a shop. ${ }^{29}$ Of course this will influence the next choice when you drink coffee again. When he is going to buy his coffee for a second time, he will think and take into account about the possibility of coffee taste, whether it will give the same taste, or more or less flavor. That in the second interaction will determine one's rational choice.

In addition, it is observed the study of rational choice theory towards the students alternative studying in Langsa that the benefits achieved are a form of student helplessness towards greater resources. Financially, students choose to study in Langsa due to their inability to study in other areas that are considered more expensive. Likewise, some students choose to study in Langsa due to their powerlessness to pass the passing grade determined by other universities.

But in the current phenomenon, students' choice to study in Langsa are based on the alternative financial benefits can be justified. It is because of various conditions of Langsa that still offers relatively inexpensive living cost. Likewise, the tuition fees tend to be cheaper compared to universities in North Sumatra.

${ }^{28}$ Isa Anshort, "Perilaku Memilih Lembaga Pendidikan," in Prosiding Seminar Nasional, Universitas Muhammadiyah Sidoarjo, 2017, p. 136-160.

${ }^{29}$ Kahneman and Tversky, "Choices, Values, and Frames," p. 341. 


\section{Identity Negotiation Among Students in a Social Area in Langsa}

From the description above, it can be seen that basic difference between Muslim and Christian students is the belief system. In identity theory, a belief system is a form of cultural identity that is a source of primary identity. For actors, primary identity relates to fulfilling individual needs so that its existence often forms conflicts, especially in terms of differences in respective values. Therefore, a negotiation process is needed so that when the interaction of actors with other actors with different identities do not result a conflict. It is different from the condition when the actor is in their own cultural identity. They are easy to communicate, stability and satisfaction because they are valued and supported.

Conducting a negotiation process is not as easy as opposite down hands, various identities of values in the social area allow collisions or vice versa so that culture shock is very likely to happen. Ting Toomey defines that culture shock is a condition that a person feels uncomfortable and feels like a threat to his well-being when he is in a new environment. ${ }^{30}$ The same conditions were experienced by Muslim and Christian students when they are interacting for the first time. Initially Eka felt strange from the social and cultural conditions of Langsa. The implementation of Islamic law as a regional law makes Langsa different from other regions in Indonesia which is predominantly Muslim. The same information was also stated by Mathius.

The same condition is also felt by some Muslim students, Yanti as a student from Muslim regions felt strange with the condition when she had to be together and sit side by side with non-Muslims. Likewise other students, they experienced a cultural shock at the beginning of the interaction. This phenomenon is experienced because they perceive different new socio-cultural conditions. De Vito in Sonny Kristian termed "crisis" after "honeymoon". ${ }^{31}$ Where a person imagines the most beautiful, happier, more comfortable, and all forms of things that are pleasing to a condition, but when she/he is in a new social culture she/he will feel "strangeness" (crisis).

Culture shock, it does not last long when the actor interacting with new social culture. Both Muslim and non-Muslim students can negotiate identities, and the identities negotiation is seen as a solution for culture shock. ${ }^{32}$ Identity negotiation between actors in the college area following the functional biculturalism pattern, they are setting of self-understanding, exploring and respecting people's identities. ${ }^{33}$ In this case, the actor strengthens his identity, but he is also able to accept flexibly and respects other identities. Non-Muslim students remain in their own identity but accept and respect different identities. For example, in

${ }^{30}$ Analisa, et al., "Negosiasi Identitas Penarik Becak Wanita", in Komunikasi, Vol. 9 No. 2. 2015.

${ }^{31}$ Desma Lina dan Dwi Budi Setiawan, "An Analysis of Culture Shock from West to East as Seen in Reilly's The Tournament," in Teknosastik, Vol. 15, No. 1, 2017, p. 14-19.

${ }^{32}$ Littlejohn and Foss, Teori Komunikasi (Jakarta: Selemba Humanika, 2009), p. 90.

33 Ibid, p. 133. 
the college system they can accept system that has become a tradition, even though it is different from their identity, but they do not participate in the tradition. This is an effort made by actors to be accepted in space with different identities. But they strengthen their identity before, and then they show their identity on how people see it.

In addition, identity negotiations with the pattern of functional biculturalism were carried out at the discretion of corporate actors (college) by giving freedom to students to determine lecturer for their religion subject. Students may choose pastor as lecturer for their religion subject and it is also given opportunities for non-Muslim students to study Islam. As Angelina did, she studied a subject of Islamic religion. The negotiation process is described functional biculturalism. Identity as their characteristic is still maintained, so that it displays two different identities. In this case, there was a shift from Ansor's research which is showed dominance and intolerance in student interactions. Negotiation is understood to accept identity of a majority. ${ }^{34}$ It is such as students have to wear a headscarf when they were in college.

The shifting is increasingly visible when it is forming tolerance in negotiations among students which is facilitated by the student community organization. The Students Executive Board of the engineering Faculty held a "night of intimacy" after college orientation was implemented. In this activity all students from various religions and social groups are united in a relation of the engineering students, there are no racial and religious differences, even students are prohibited from joining groups of fellow and religious people. Mixing students with different identities is done as a form of eliminating students' culture shock. In addition, the Faculty of Teacher Training and Education also unites students from different identities, but they tend to engage in student group discussions consisting of students from various ethnic groups and religions in one group.

The data description above shows how Muslim and non-Muslim students interact and negotiate in the college area. Initially different identities can be negotiated so it is formed a new cultural state from the results of negotiations (cultural transformers). This shows that identity negotiation in college area between Muslim and non-Muslim student is effective. The achievement of its objectives is seen from the influence and role of college as a corporate actor in forming students. College is seen to be able in forming an environment that accommodates differences.

However, this condition cannot guarantee students' interaction outside of college. Social spaces, structures and norms that are formed in communities outside college are not formatted for conditions to accommodate different identities. But they have their own habits in handling differences. This gives a signal for Muslim and non-Muslim students to be able to form negotiation strategies in order to be able to adapt to different identities, while at the same time being able to recover from culture shock of the initial negotiation process.

${ }^{34}$ Ansor, "Menjadi Seperti Beragama Lain,” p. 11-30. 
There are two alternative strategies that are carried out to restore the culture shock of the initial negotiation, they are: choosing to live with person of the same identity, or choosing to live together with a person of different identity. For students who live with a person of the same identity, identity negotiation is carried out only limited to ethnic differences. NonMuslim students who are Bataknese negotiate with other Bataknese of different clans. As the condition of non-Muslim students who live in Sinar Mata in Sidorejo street area, they are all Bataknese, but their origin and clans are different. Likewise, the conditions of Muslim students living among fellow Muslims, negotiations occur are only limited to different regions or ethnicities. The condition at first glance looks the same as Cahyo Pamungkas research in Ambon, after the conflict there was a tendency for religious communities to choose to livein homogeneous environment. ${ }^{35}$

There is a different phenomenon from students who are living in different cultural setting. The process of identity negotiation carried out looks like more complicated and careful, because what they are facing is students with different religious and ethnic background, mistakes in doing so will result in intolerance and can even lead to conflict. From interview with informants who occupy boarding houses that have various religious identities, the negotiation process begins with the recovery phase. Actors try to understand the conditions of culture, language, and habit of other actor in the new environment. ${ }^{36}$

At this stage, each student of different religion tries to understand the religious traditions of other students. Non-Muslim students try to understand Muslim students, and vice versa, Muslim students understand non-Muslim students. In various situations each student will understand each other's identity. Eka as one of non-Muslim students admitted to initiating intimacy with Muslim students by understanding their habits, including the matters of worship. Selvi's recognition as one of the Muslim students also acknowledged the same thing, namely understanding habits as the first step in approaching.

After each of them understands each other's religion and culture, the actor negotiates identity. At this stage students follow functional biculturalism pattern, in which each students reinforces his identity to understand other identities. In this process actors set their identity as reinforcement, and then negotiate to form tolerance in order to understand different identities. Eka recounts her experience negotiating with Muslim students in the form of eating together, and appreciating them when they do Maghrib praying. Likewise Muslim students are willing to help make up non-Muslim students when they want to go to church.

The visualization shows how the form of identity negotiation is practiced by each student who has a different religion. They try to understand other's identity, at the same

${ }^{35}$ Cahyo Pamungkas, "Social Contexts of Exclusionary Reactions: Study on Muslim and Christian Relation in the City of Ambon," in IJIMS, Vol. 5, No. 1, June 2015, p. 49-74.

${ }^{36}$ Joseph A Devito, Komunikasi Antarmanusia (Tangerang: KARISMA Publishing Group, 2011), p. 550. 
time they also strengthen each other's identity. The habit of carrying out religious routines for each student shows the level of strengthening of each person's identity. Eka always go to church on Sundays, as well as Muslim students, they continue to carry out their religious routines, such as praying, fasting, and so on. Likewise, the shared attitude displayed further clarifies the pattern of functional biculturalism practices in identity negotiations between religions. This condition was also reinforced by selvi's who lived in one boarding house with Eka.

In addition, the prevailing habits in Netty's boarding house also show a pattern of functional biculturalism in negotiating identity. Netty's recognition that living in Muslim students majority, she also practices tolerance. The habit of cooking together and mutual respect when carrying out worship is a form of functional biculturalism. On Friday morning, Netty along with Muslim boarding friends always carry out cooking together. They carry out the activities together, from shopping to markets to eating together. Likewise in worship they are seen having mutual respect. Non-Muslim students never carry out any activities during praying times, especially at evening praying as a form of respect for Muslim friends worshiping. The same thing is done by Muslim students, sometimes they also help to prepare the needs of non-Muslim students when they go to church, such as dressing, and others.

The same condition was also occurred in Pak Simbolon's boarding houses, even though they were Muslim minorities, but in their daily lives they also practice tolerance in identity negotiations. There are many others information, where they carry out functional biculturalism patterns in identity negotiations. The problem is how each actors feeling when they are dealing with the boundaries of identity claims, such as the fear of Muslim students against the habit of non-Muslims of consuming "pork". This condition is actually thought by Christian and Muslim students. And for non-Muslim students do not consume pork when they are in Langsa is part of the negotiation to respect identity diversity systems. Netty recounted that there was problem when they were forming interaction with Muslim students due to prejudice, but it was overcome through negotiations being built.

The illustration shows how non-Muslim students came out of an identity crisis when Muslim students had "suspicion" of non-Muslim student habits. According to the theory of identity negotiation, the condition is considered reasonable because someone who has a displacement (dislocation) will experience negative feeling or negative view by the social in a new place. This condition will continue until the actor makes a recovery by interacting and negotiating with identity in a different reality. When it is viewed from the efforts made by utilizing other sources to find out identity, non-Muslim students have actually used active method to reduce suspicion. Charles and James Bradac in Yusri Fajar defined that active strategy with the efforts taken by someone to find information about other people by asking or suggesting strategies. ${ }^{37}$ Indeed, it is not easy for non-Muslim students, when

${ }^{37}$ Yusri Fajar, "Negosiasi Identitas Pribumi dan Belanda dalam Sastra Poskolonial Indonesia Kontemporer," in Literasi, Vol. 1, No. 2 Desember 2011, p. 178-186. 
they have to abandon their own habits that are considered to be part of themselves just to negotiate with external reality. But due to various factors of interest doing such a thing has been considered as part of capital to achieve profits.

From explanation of negotiation carried out by Muslim and non-Muslim students in Langsa, it shows Mindfulness. Although the identities of the two are different, it does not become an obstacle for students to interact and communicate. Indeed, it cannot be denied if we look at the Toomey's assumption that identity comfort is obtained in a cultural environment that is familiar for actors. On the contrary, identity is very vulnerable if it is in a new environment. It not only on that such a thing, even at the response level actors will be easy to get a positive response in the same group membership, and actor will get unfamiliar conditions and even negative responses if they are in a new environment. ${ }^{38}$ But this will not last long when actors are able to negotiate in different environments. Unfamiliar, negative response as it is described by Toomey turn into Mindfulness and eventually a different culture will be formed from the results of the negotiations that were built.

Although in some respects it is undeniable there are still students, both in Muslim and non-Muslim tend to get used to familiar habits, they prefer to a lifestyle with the same tendency. This effort was made to facilitate communication. For this group, seeing that communicating with individuals from the same identity is easier than they are from different identity. Likewise, they will feel that there is strengthening and trust in their identity when they are interacting with the same or almost the same culture, whereas actor tend to get identity shakiness when they are interacting with individuals from different cultures, moreover when they are communicating in the bonding regulation of cultural differences. In this condition, students tend to be mindless. They are only used to familiar people with them, and are not familiar with other individual and group. Identity negotiation with different cultures occurs in the college environment.

Although in negotiation students display two attitudes, namely Mindfulness and mindless, but in social life there is no limit for each students to present and to articulate their identity. Muslim students as the majority can actualize their identities and do not dominate the minority, and vice versa, non-Muslim students can also present their identities without feeling dominated. So that it will display a variety of cultural interactions in social life in Langsa.

From the description above shows that Muslim and non-Muslim students are as effective actors in identity negotiations. They feel comfortable even in different cultural and structural systems. Their differences do not necessarily have implications to conflict. Instead they can be tolerant in living their daily lives. In this case, there is no more effort to dominate in interacting. Actor as a minority does not have to be a majority. Interaction does not have to be understood by being someone else. As Hans Kung stated that religious tolerance is

\footnotetext{
${ }^{38}$ Toomey, Communication Across, p. 247.
} 
not forcing others to live similarly to a majority identity, but it is accepting the diversity of each identity ${ }^{39}$ The same phenomenon is seen in religious interactions in Albertus' research, where religious communities can interact in the dimensions of their respective beliefs. ${ }^{40}$

In this case, the authors see there is a shift from the Ansor's presented thesis in the study of Hijab and Reproduction of the Identity of Christian Women in the Aceh School Public Space, where non-Muslims feel dominated by the social system and structure in Aceh. Coercion on wearing headscarves in the workspace is a social burden for non-Muslims to carry out complex negotiations. Such a negotiation carried out is how to be a part of a different identity, even though they are out of self-identity bonding. Likewise in the article Becoming Like Other Religions: Hijab and Hybrid Identity Aceh Christian Students, which describe non-Muslim students as having to wear headscarves as a form of accepting part of the Islamic Shari'a negotiation, as well as resistance in other parts. In addition, educational institutions which are described as public spaces should accommodate differences, instead creating an attitude of intolerance in interreligious relations. ${ }^{41}$

A very visible shifting is the freedom of non-Muslim students to present their identities, both in educational institutions and social environment. They do not have to be part of another group in negotiating. The initial identity as their identity formed by each social system is still maintained so as to form a routine, as a new social system that is formed from negotiation of two different identities. This shows that identity negotiation built by Muslim and non-Muslim students are effective.

\section{Conclusion}

The objective conditions of student life in Langsa display a harmonious life. It has already built a tolerant way of life. This condition indicates a shift from the previous condition. In several studies conducted, it was shown that student life between religions in Langsa showed intolerance. In various conditions non-Muslim students are dominated and they are required to be as others in cultural space. Choosing to be students in a different space is caused by several reasons, they are: First, college status. Second, the results of the try out college entrance test. Third, it is suggestions of schools. fourth, friends or relatives' invitation, and fifth, conducive environment.

From various reasons and motives behind the students choosing universities in Langsa, it can be concluded that the rational choice of students studying in Langsa is based on two main factors, namely: experience value and decision value. Experience value is something

${ }^{39}$ Hans Kung, Jalan Dialog (Yogyakarta: CRCR, 2009), p. 24.

${ }^{40}$ Albertus Bagus Laksana, "Naming God Together: Muslim-Christian Theology of Mercy in the Indonesia Context," in Journal of Asian Orientation in Theology, Vol. 1, No. 1 February 2019, p. 1-30.

${ }^{41}$ Ansor, "Menjadi Seperti Beragama Lain," p. 11-30. 
that is very much related to pleasure or pain, satisfaction or disappointment, and gains or losses that are taken into consideration in the determination. Meanwhile the decision value is the general expectation about the attraction or resistance of the choices available. Negotiations carried out by Muslim and non-Muslim students in Langsa cultural spaces follow a functional biculturalism pattern, which begins through strengthening self-identity to respect other identities. But beforehand, in building negotiations students were initiated by a condition that felt strange and different in new conditions (culture shock).

\section{References}

Analisa, et al. "Negosiasi Identitas Penarik Becak Wanita," in Komunikasi, Vol. 9 No. 2. 2015.

Anshort, Isa. "Perilaku Memilih Lembaga Pendidikan," in Prosiding Seminar Nasional, Universitas Muhammadiyah Sidoarjo, 2017.

Ansor, Muhammad dan Cut Intan Meutia. "Jilbab dan Reproduksi Identitas Perempuan Kristen Ruang Publik Sekolah Aceh," in Kawistara, Vol. 7 No. 2 Agustus 2016.

Ansor, Muhammad. "Kan Kan Berbeda!: Persamaan Remaja Perempuan Muslim dan Kristen di Langsa Aceh," in Harmoni, Vol. 13 No. 2, 2014.

Ansor, Muhammad. "Menjadi Seperti Beragama Lain: Jilbab dan Identitas Hibrid Mahasiswa Kristen Aceh," in Penamas: Jurnal Penelitian Keagamaan dan Kemasyarakatan, Vol. 29, No. 1 April-Juni 2016.

Ansor, Muhammad. "Salib Dibalik Jilbab: Negosiasi Identitas Perempuan Kristen Berjilbab di Langsa Aceh," in Proceeding ACIS XIV, 2014.

Arsita, Meita, et al. "Rasionalitas Pilihan Orang Tua Terhadap Pesantren sebagai Lembaga Pendidikan Remaja Awal, Sosialitas," in Journal Ilmiah Pendidikan SosiologiAntropologi, Vol. 5 No. 2, 2015.

Aryani, Sekar Ayu. "Orientasi Sikap dan Perilaku Keagamaan: Studi Kasus Mahasiswa Salah Satu Perguruan Tinggi Negeri di DIY," in Religi Jurnal Studi-Studi Agama, Vol.XI, No. 1, 2015.

Bahari (ed.). "Toleransi Beragama Mahasiswa: Studi tentang Pengaruh Kepribadian, Keterlibatan Organisasi, Hasil Belajar Pendidikan Agama, dan Lingkungan Pendidikan terhadap Toleransi Mahasiswa Berbeda Agama pada 7 Perguruan Tinggi Umum Negeri”. Jakarta: Badan Litbang dan Diklat Puslitbang Kehidupan Keagamaan, 2010.

Coleman, James. Dasar-Dasar Teori Sosial. Bandung: Nusa Media, 2011.

Creswell, John W. Research Design: Qualitative, Quantitative and Mixed Methods Approaches Second Edition. California: Sage Publication, Inc., 2003.

Devito, Joseph A. Komunikasi Antarmanusia. Tangerang: KARISMA Publishing Group, 2011. 
Fajar, Yusri. "Negosiasi Identitas Pribumi dan Belanda dalam Sastra Poskolonial Indonesia Kontemporer," in Literasi, Vol. 1, No. 2, 2011.

Geertz, Clifford. The Religion of Java. Chicago and London: The University of Chicago Press, 1960.

Irwansyah, Irwansyah. "Interaksi Muslim dan Kristiani dalam Ikatan Kekerabatan di Sumatera Utara," in MIQOT: Jurnal Ilmu-ilmu Keislaman, Vol. 41, No. 1, 2017.

Irwansyah, Irwansyah. "Hubungan Muslim-Kristiani dalam Lembaga Pendidikan di Sumatera Utara, in Journal of Contemporary Islam and Muslim Societies, Vol. 1, No. $2,2017$.

Kahneman, Daniel, Amos Tversky. "Choices, Values, and Frames," in American Psychologist Association (APA), University of Brittish Columbia, April 1983.

Kung, Hans. Jalan Dialog. Yogyakarta: CRCR, 2009.

Laksana, Albertus Bagus. "Naming God Together: Muslim-Christian Theology of Mercy in The Indonesia Context," in Journal of Asian Orientation in Theology, Vol. 1, No. 1 February 2019.

Lina, Desma dan Dwi Budi Setiawan. "An Analysis of Culture Shock from West to East as Seen in Reilly's The Tournament," in Teknosastik, Vol. 15, No. 1, 2017.

Littlejohn \& Foss. Teori Komunikasi. Jakarta: Selemba Humanika, 2009.

Manshuruddin. "Pola Kerukunan Antar Umat Beragama dalam Perspektif Forum Kerukunan Umat Beragama (FKUB) Sumatera Utara," in MIQOT: Jurnal Ilmu-ilmu Keislaman, Vol. 41 No. 2, 2017.

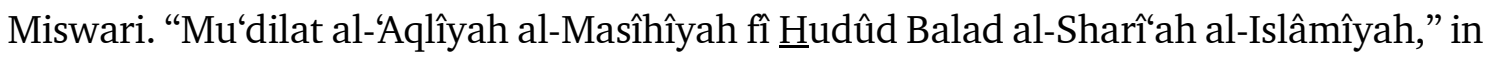
Studia Islamika, Vol. 25, No. 2, 2018.

Norman K. Denzim dan Yvonna S. Lincoln. Handbook of Qualitative Research, terj. Dariyanto, et al. Yogyakarta: Pustaka Pelajar, 2009.

Pamungkas, Cahyo. "Social Contexts of Exclusionary Reactions: Study on Muslim and Christian Relation in the City of Ambon," in IJIMS, Vol. 5, No. 1, June 2015.

Randa, Ignasius Resky Alsuka. "Sikap Toleransi Mahasiswa Lintas Etnis dan Agama di Asrama Bujang Malaka Kabupaten Kubu Raya," in Pendidikan dan Pembelajaran, Vo. 6, No. 32017.

Toomey, Stella Ting. Communication Across Cultures. London: The Guldford Press, 1999. 